glycine, alanine and threonine. With the possible exception of aspartic acid these are considered to arise from hydrolysis of peptide bonds during the treatments. Aspartic acid is either a terminal residue which is inaccessible to fluorodinitrobenzene or the peptide bond involving its $\alpha$-amino group is especially labile.

Thanks are due to the Council of the British Leather Manufacturers' Research Association for permission to publish this paper.

\title{
REFERENCES
}

Adair, G. S., Partridge, S. M. \& Davis, H. F. (1951). Nature, Lond., 167, 605.

Bailey, K. (1951). Biochem. J. 49, 23.

Bear, R. S. (1952). Advanc. in Protein Chem. 7, 69.

Blackburn, S. (1949). Biochem. J. 45, 579.

Blackburn, S. (1950a). Biochem. J.47, 443.

Blackburn, S. (1950b). Biochem. J. 47, xxviii.

Bowes, J. H. \& Kenten, R. H. (1948a). Biochem. J. 43, 358. Bowes, J. H. \& Kenten, R. H. (1948b). Biochem. J. 43, 365. Doherty, D. G. \& Ogg, C. L. (1943). Industr. Engng Chem. (Anal.), 15, 75.

Garner, J. B., Saxton, B. \& Parker, H. O. (1911). Amer. chem. J. 46, 236.

Humphrey, J. H. (1946). Biochem. J. 40, 442.

Jackson, D. S. (1952). Biochem. J. 54, 638.

Mathews, M. B., Roseman, S. \& Dorfman, A. (1951). J. biol. Chem. 188, 327.

Middlebrook, W. R. (1949). Nature, Lond., 164, 501.

Middlebrook, W. R. (1951). Biochim. biophys. Acta, 7, 547.
Mills, G. L. (1950). Nature, Lond., 165, 403.

Moore, S. \& Stein, W. H. (1951). J. biol. Chem. 192, 663.

Orekhovich, V. N., Tustanovskii, A. A., Orekhovich, K. D. \& Plotinkova, N. E. (1948). Biochemistry, Leningr., 13, 55.

Partridge, S. M. \& Davis, H. F. (1950). Nature, Lond., 165, 62.

Pauling, L. \& Corey, R. B. (1951). Proc. nat. Acad. Sci., Wash., 37, 272.

Porter, R. R. (1948). Biochim. biophys. Acta, 2, 105.

Porter, R. R. \& Sanger, F. (1948). Biochem. J. 42, 287.

Pouradier, J. \& Venet, A. M. (1950). J. Chim. phys. 47, 11.

Sanger, F. (1945). Biochem. J. 39, 507.

Sanger, F. (1952). Advanc. in Protein Chem. 7, 1.

Tsao, T. C., Bailey, K. \& Adair, G. S. (1951). Biochem. J.49, 27.

Weygand, F. \& Junk, R. (1951). Naturwissenschaften, 38, 433.

\section{The Catalytic Effect of Molybdate on the Hydrolysis of Organic Phosphates}

\author{
BY H. WEIL-MALHERBE \\ Research Department, Runwell Hospital, Wickford, Essex
}

(Received 16 May 1953)

Lutwak \& Sacks (1953) recently investigated the effect of molybdate on the hydrolysis of organic phosphates at a temperature of $100^{\circ}$. Two series of experiments were carried out, one at a $\mathrm{pH}$ of about 5.5 and the other in $\mathrm{N}$ sulphuric acid. The inorganic phosphate formed after certain time intervals was determined by two methods: $(a)$ by direct colorimetric estimation according to Fiske \& Subbarow (1925), and (b) by precipitation with magnesia mixture, followed by a colorimetric analysis of the dissolved precipitate. Both methods were in agreement when samples were analysed, which did not contain molybdate during heating; on the other hand, when organic phosphates were heated together with molybdate, the inorganic phosphate estimated by the direct colorimetric method was considerably in excess of that estimated after precipitation with magnesia mixture; it was, moreover, often in excess of the theoretical value for complete hydrolysis, in one case by about $400 \%$. These results were interpreted as indicating the formation of organophosphomolybdate complexes, not precipitable by magnesia mixture, but reducible by the Fiske-Subbarow reagent. If this interpretation were correct, it would cast doubt on the significance of some of the results obtained earlier by WeilMalherbe \& Green (1952) in an investigation in which the molybdate effect was studied under different experimental conditions and with a different analytical technique. It was therefore of interest to find out $(a)$ whether the effect of Lutwak \& Sacks would be observed with their analytical techniques under the milder experimental conditions that were used in most of the experiments of Weil-Malherbe \& Green, i.e. at a temperature of $80^{\circ}$ or less and in the $\mathrm{pH}$ range between 3 and 6 ; and (b) whether it could be observed under the more rigorous conditions of Lutwak \& Sacks with the analytical technique of Weil-Malherbe \& Green who used a stannous chloride method of phosphate 
estimation (Martin \& Doty, 1949). The hydrolysis of three of the compounds used in the American investigation was therefore determined under the following conditions: (i) at $\mathrm{pH} 5 \cdot 5$ and $80^{\circ}$, (ii) in $\mathrm{N}$ acid at $100^{\circ}$, and by the following methods: $(a)$ that of Martin \& Doty (1949) using stannous chloride as reducing agent, (b) that of Fiske \& Subbarow (1925) using aminonaphthol sulphonic acid and (c) after precipitation with magnesia mixture.

\section{EXPERIMENTAL}

The test solutions contained $1 \%$ ammonium molybdate and either $0.05 \mathrm{M}$ sodium acetate-acetic acid buffer, $\mathrm{pH} 5 \cdot 5$, or $\mathrm{N}-\mathrm{H}_{2} \mathrm{SO}_{4}$. The substrate concentration was $1 \cdot 6 \mathrm{~mm}$. The substrates used were: fructose 6-phosphate, adenosine 5'phosphate and sodium phenyl phosphate. Samples for the estimation of inorganic phosphate were withdrawn at zero time and after 2 and $4 \mathrm{hr}$.

Analytical methods. The modification of the method of Martin \& Doty (1949) used in this laboratory has been described (Weil-Malherbe \& Green, 1952). We now use the isobutanol-benzene mixture as recommended by Martin \& Doty for the extraction; it produces a better separation of the phases, especially after perchloric acid digestion. A $4 \mathrm{ml}$. sample of the extract was withdrawn, instead of $5 \mathrm{ml}$. which were sometimes difficult to obtain, and was mixed with $4 \mathrm{ml}$. acid ethanol and $0 \cdot 2 \mathrm{ml}$. of dilute $\mathrm{SnCl}_{2}$ solution.

The method of Fiske \& Subbarow was used in the modification of Umbreit, Burris \& Stauffer (1945).

Precipitation with magnesia mixture was carried out on a $20 \mathrm{ml}$. sample. After the solution had been made alkaline to phenolphthalein with $\mathrm{NH}_{3}$, a further $2 \mathrm{ml}$. of conc. $\mathrm{NH}_{3}$ soln. (sp.gr. $0 \cdot 880$ ) and $2 \mathrm{ml}$. of magnesia mixture (5 g. $\mathrm{MgCl}_{2}, 6 \mathrm{H}_{2} \mathrm{O}, 10 \mathrm{~g}$. $\mathrm{NH}_{4} \mathrm{Cl}$ and $10 \mathrm{ml}$. conc. $\mathrm{NH}_{3}$ soln. made up to $100 \mathrm{ml}$. with water) were added. The solution was left at $3^{\circ}$ for $18 \mathrm{hr}$. After washing with $2 \% \mathrm{NH}_{3}$ soln. the precipitate was dissolved in acid and estimated by the method of Martin \& Doty.

\section{RESULTS}

\section{Comparison of phosphate methods}

All three methods of phosphate estimation were in agreement in the experiments carried out at pH 5.5 and $80^{\circ}$, whether molybdate was present or not (Table 1). The differences observed may be ascribed to analytical errors; they do not substantiate the existence of the effect under these conditions. No blue colour developed in the samples heated with molybdate.

In the experiments performed at $100^{\circ}$ in $\mathrm{N}$ acid agreement between the three methods of estimation was again reasonable when molybdate was absent. On the other hand, with fructose 6-phosphate or adenosine $5^{\prime}$-phosphate as substrate and with molybdate present, the three methods gave strikingly different results. Those obtained with the method of Fiske \& Subbarow greatly exceeded the theoretical value for complete hydrolysis. This was not the case when the method of Martin \& Doty was used, but even then the results were higher than those obtained after precipitation with magnesia mixture (Table 1).

An intense-blue colour developed in these samples during the exposure to heat. With phenyl phosphate as substrate the solution turned bright green, presumably owing to the admixture of some blue colour to a yellow background of phosphomolybdic acid. Here the effect of Lutwak \& Sacks was much less in evidence. Again 'phosphate by precipitation' agreed better with 'phosphate by Martin \& Doty' than with 'phosphate by Fiske \& Subbarow'.

As to the catalytic effect of molybdate at $\mathrm{pH} 5.5$ and $80^{\circ}$, it was absent with phenyl phosphate, slight

\section{Table 1. Hydrolysis of organic phosphates}

(M. \& D., method of Martin \& Doty (1949); F. \& S., method of Fiske \& Subbarow (1925); Mg, precipitation with magnesia mixture.)

Compound Conditions

Sodium phenyl phosphate

$$
80^{\circ}, \mathrm{pH} 5 \cdot 5
$$$$
100^{\circ}, \mathrm{N}-\mathrm{H}_{2} \mathrm{SO}_{4}
$$$$
80^{\circ}, \mathrm{pH} 5 \cdot 5
$$

Fructose 6-phosphate

Adenosine 5' -phosphate

\begin{tabular}{|c|c|c|c|c|c|c|c|}
\hline \multirow{3}{*}{$\begin{array}{c}\text { Time } \\
\text { (hr.) }\end{array}$} & \multirow{2}{*}{\multicolumn{3}{|c|}{ Without molybdate }} & \multicolumn{4}{|c|}{ With molybdate } \\
\hline & & & & & & & Blue \\
\hline & M. \& D. & F. \& S. & $\begin{array}{c}\mathrm{Mg} \\
\text { Hydrol }\end{array}$ & $\begin{array}{l}\text { M. \& D. } \\
\text { sis (\%) }\end{array}$ & F. \& S. & $\mathrm{Mg}$ & colour \\
\hline $\begin{array}{l}2 \\
4\end{array}$ & $\begin{array}{l}14 \cdot 8 \\
26 \cdot 3\end{array}$ & $\begin{array}{l}13 \cdot 0 \\
25 \cdot 4\end{array}$ & $\begin{array}{l}13 \cdot 9 \\
25 \cdot 6\end{array}$ & $\begin{array}{l}14 \cdot 1 \\
28 \cdot 3\end{array}$ & $\begin{array}{l}15 \cdot 0 \\
27 \cdot 0\end{array}$ & $\begin{array}{l}14 \cdot 6 \\
25.9\end{array}$ & - \\
\hline $\begin{array}{l}2 \\
4\end{array}$ & $\begin{array}{l}29 \cdot 8 \\
55 \cdot 8\end{array}$ & $\begin{array}{l}30 \cdot 2 \\
53 \cdot 9\end{array}$ & $\begin{array}{l}26.9 \\
53.9\end{array}$ & $\begin{array}{l}49 \cdot 5 \\
72 \cdot 7\end{array}$ & $\begin{array}{l}56 \cdot 7 \\
83 \cdot 6\end{array}$ & $\begin{array}{l}41 \cdot 6 \\
67 \cdot 5\end{array}$ & + \\
\hline $\begin{array}{l}2 \\
4\end{array}$ & $\begin{array}{r}5 \cdot 1 \\
10 \cdot 2\end{array}$ & $\begin{array}{l}4 \cdot 5 \\
9 \cdot 8\end{array}$ & $\begin{array}{r}4 \cdot 8 \\
10 \cdot 0\end{array}$ & $\begin{array}{l}23 \cdot 6 \\
36 \cdot 0\end{array}$ & $\begin{array}{l}24 \cdot 1 \\
36 \cdot 0\end{array}$ & $\begin{array}{l}24 \cdot 0 \\
35 \cdot 8\end{array}$ & - \\
\hline $\begin{array}{l}2 \\
4\end{array}$ & $\begin{array}{l}36 \cdot 2 \\
57 \cdot 8\end{array}$ & $\begin{array}{l}32 \cdot 2 \\
59 \cdot 2\end{array}$ & $\begin{array}{l}32.9 \\
54 \cdot 5\end{array}$ & $\begin{array}{l}61 \cdot 7 \\
71 \cdot 4\end{array}$ & $\begin{array}{l}333 \\
364\end{array}$ & $\begin{array}{l}37.9 \\
56 \cdot 5\end{array}$ & $\begin{array}{l}+++ \\
+++\end{array}$ \\
\hline $\begin{array}{l}2 \\
4\end{array}$ & $\begin{array}{l}0.9 \\
1.8\end{array}$ & $\begin{array}{l}1.2 \\
1.8\end{array}$ & $\begin{array}{l}0.9 \\
1.8\end{array}$ & $\begin{array}{l}1.8 \\
3.4\end{array}$ & $\begin{array}{l}2 \cdot 6 \\
3 \cdot 4\end{array}$ & $\begin{array}{l}1.7 \\
3.2\end{array}$ & - \\
\hline $\begin{array}{l}2 \\
4\end{array}$ & $\begin{array}{l}14.8 \\
30.9\end{array}$ & $\begin{array}{l}13 \cdot 6 \\
30 \cdot 7\end{array}$ & $\begin{array}{l}12.7 \\
27.3\end{array}$ & $\begin{array}{l}80 \\
89\end{array}$ & $\begin{array}{l}419 \\
458\end{array}$ & $\begin{array}{l}32 \\
36\end{array}$ & $\begin{array}{l}+++ \\
+++\end{array}$ \\
\hline
\end{tabular}


Table 2. Recovery of inorganic phosphate

(Final concns. $\mathrm{KH}_{2} \mathrm{PO}_{4}, 1.6 \mathrm{mM}$; fructose, $3.33 \mathrm{~mm} ; \mathrm{H}_{8} \mathrm{SO}_{4}$, $1 \mathrm{~N}$. Temp. $100^{\circ}$. M. \& D., method of Martin \& Doty (1949); F. \& S., method of Fiske \& Subbarow (1925); Mg, precipitation with magnesia mixture.)

\begin{tabular}{|c|c|c|c|c|c|c|c|}
\hline \multirow{2}{*}{$\begin{array}{r}\text { Time } \\
\text { (hr.) }\end{array}$} & \multicolumn{3}{|c|}{ Without molybdate } & \multicolumn{4}{|c|}{ With $1 \%$ ammonium molybdate } \\
\hline & M. \& D. & F. \& S. & Mg & M. \& D. & F. \& S. & $\mathrm{Mg}$ & Blue colour \\
\hline \multicolumn{8}{|c|}{ Recovery (\%) } \\
\hline 0 & 100 & $102 \cdot 8$ & $95 \cdot 2$ & 100 & 101.5 & 89.5 & - \\
\hline 2 & $101 \cdot 5$ & $102 \cdot 0$ & $93 \cdot 1$ & 150 & 595 & 54.5 & +++ \\
\hline 4 & $104 \cdot 1$ & $103 \cdot 9$ & $96 \cdot 2$ & 168 & 700 & $54 \cdot 5$ & +++ \\
\hline
\end{tabular}

with adenosine $5^{\prime}$-phosphate and strong with fructose 6-phosphate. The last result confirms previous observations (Weil-Malherbe \& Green, 1952). At $\mathrm{pH} 0$ and $100^{\circ}$ the catalytic effect of molybdate was evident in the case of phenyl phosphate, but cannot be assessed in the experiments with the other two substrates.

\section{Recovery experiments}

It was concluded from these results that the effect of Lutwak \& Sacks is connected with the formation of blue colour during the exposure to heat. The recovery of inorganic phosphate was therefore studied under conditions in which the formation of molybdenum blue and phosphomolybdenum blue could be expected. Fructose $(0.06 \%)$ was used as reducing agent, so as to approximate the conditions of the experiment to those in which the hydrolysis of fructose 6-phosphate was studied. The experiment included two controls, one in which molybdate, and one in which phosphate was absent.

The results are shown in Table 2. Again, the samples containing molybdate developed an intense-blue colour during heating, not only in the presence of phosphate, but also in its absence. Recoveries in absence of molybdate were quantitative, the slight increase found with the colorimetric methods probably being due to evaporation losses. In presence of molybdate extremely high values were obtained with the Fiske \& Subarrow method. With the method of Martin \& Doty, too, erroneously high values were obtained but the error was about one-tenth of that incurred with the method of Fiske \& Subbarow. With the precipitation method, on the other hand, the recoveries of inorganic phosphate were low.

The blue pigment which developed in absence of inorganic phosphate could be extracted from acid solutions by isobutanol, contrary to statements contained in the literature. It was partly extracted when the acidity was $0.5 \mathrm{~N}$, and completely, when the acidity was $1 \mathrm{~N}$ or higher.

\section{DISCUSSION}

Our results suggest that the effect of Lutwak \& Sacks is only observed if a blue colour develops during the period of heating with molybdate. The colour development may be attributed to the reducing action of the organic component of the phosphate ester. No colour development occurred in the experiments reported in our first paper (WeilMalherbe \& Green, 1952) and accordingly no indication of the effect was obtained. On several occasions hydrolysis was allowed to go to completion, but colour intensities exceeding the theoretical value were not observed (see, for example, Fig. 13, WeilMalherbe \& Green, 1952). In the present work no colour developed at $\mathrm{pH} 5.5$ and $80^{\circ}$ and the phosphate estimations by the three methods were in agreement. Contrary to the claims of Lutwak \& Sacks their figures do not bear out the existence of the effect in those of their experiments carried out at $\mathrm{pH} 5.5$ and $100^{\circ}$. If the hydrolysis estimated by the precipitation method is expressed as a percentage of the hydrolysis estimated by the direct colorimetric method, the mean 'recovery', calculated from their table 1 , is $70.6 \%$ (s.E. 16.4\%) after heating without molybdate (columns 3 and 6), and $99.5 \%$ (range $88-113 \%$ ) after heating at pH 5.5 with molybdate (columns 2 and 5). The agreement is thus in fact better in the experiments with molybdate. Even in the case of phenyl phosphate, specifically quoted by Lutwak \& Sacks, the results agree within $12 \%$, which is well within the standard deviation of the series without molybdate where 'good agreement was obtained between the values found by the two procedures'.

The explanation which attributes the effect to the formation of organophosphomolybdate complexes does not seem plausible. It is improbable, though not impossible, that a complex should be formed from molybdate, fructose and inorganic phosphate which would behave similarly to a complex of molybdate with fructose 6-phosphate. Far from increasing colour development, organic phosphates, which form complexes with molybdate (e.g. $\alpha$ - 
Table 3. Specific extinction coefficients in various methods of phosphate estimation

\begin{tabular}{|c|c|c|c|c|c|}
\hline Method & $\begin{array}{l}\text { Temperature } \\
\text { of colour } \\
\text { development }\end{array}$ & $\begin{array}{l}\text { Reducing } \\
\text { agent }\end{array}$ & $\begin{array}{l}\text { Wavelength } \\
(\mathrm{m} \mu .)\end{array}$ & $E_{1}^{1 \mathrm{~g} . \mathrm{P} / \mathrm{l} .}$ & Ref. \\
\hline Fiske \& Subbarow & About $20^{\circ}$ & ANS* & $\mathbf{7 3 0}$ & 126 & This paper \\
\hline Fiske \& Subbarow & About $20^{\circ}$ & ANS & Approx. 700 & 150 & Norberg (1942) \\
\hline Teorell & About $20^{\circ}$ & ANS & Approx. 700 & 195 & Teorell (1931) \\
\hline Griswold et al. & $100^{\circ}$ & ANS & 820 & 860 & $\begin{array}{l}\text { Griswold, Humoller \& } \\
\text { McIntyre (1951) }\end{array}$ \\
\hline Lowry \& Lopez & About $20^{\circ}$ & Ascorbic acid & 700 & $140-150$ & Lowry \& Lopez (1946) \\
\hline Sumner & About $20^{\circ}$ & $\mathrm{FeSO}_{4}$ & 730 & 114 & This paper \\
\hline Boltz \& Mellon & $100^{\circ}$ & Hydrazine & 830 & 864 & Boltz \& Mellon (1947) \\
\hline Denigès & About $20^{\circ}$ & $\mathrm{SnCl}_{2}$ & Approx. 700 & 700 & Norberg (1942) \\
\hline Berenblum \& Chain & About $20^{\circ}$ & $\mathrm{SnCl}_{2}$ & Approx. 700 & 700 & Norberg (1942) \\
\hline Martin \& Doty & About $20^{\circ}$ & $\mathrm{SnCl}_{2}$ & 730 & 740 & This paper \\
\hline Fontaine & $100^{\circ}$ & $\mathrm{SnCl}_{2}$ & 820 & 950 & Fontaine (1942) \\
\hline
\end{tabular}

glycerophosphate), inhibit it (Davies \& Davies, 1932), at any rate at room temperature. In the absence of further evidence other explanations ought to be considered. In our view the effect is caused by three factors which, together, fully account for it.

The first factor is a decreased recovery of inorganic phosphate by precipitation with magnesia mixture after the reduction of the phosphomolybdate complex. This may be due to a greater resistance of the reduced complex to alkali.

The second factar is the formation of molybdenum blue, due to the reduction of free molybdic acid. Contrary to prevailing opinions, molybdenum blue is extracted from acid solutions by isobutanol. It is likely that this factor was more prevalent in the experiment in which free fructose and inorganic phosphate were heated with molybdate than in the experiment with fructose 6-phosphate. But its occurrence in the latter cannot be entirely ruled out.

The third factor is an increase of the specific extinction coefficient of the reduced phosphomolybdate complex with temperature. Table 3 contains some values of specific extinction coefficients for phosphorus, obtained by various methods of phosphate estimation. Some were collected from the literature, others were determined in this laboratory with the Unicam spectrophotometer. It appears that the effect of temperature on the specific extinction coefficient is much greater for the reducing agent of Fiske \& Subbarow (aminonaphtholsulphonic acid) than for stannous chloride. If the colour is developed at $100^{\circ}$, all reducing agents for which data are available lead to an extinction of about 800-900. Stannous chloride is the only reducing agent so far known with which a similar extinction is already obtained at room temperature. As has been shown by Berenblum \& Chain (1938), only two molybdate groups are reduced per atom of phosphorus in the method of Fiske \& Subbarow, whereas nine are reduced in the method of Kuttner \& Cohen (1927) employing stannous chloride. A slow intensification of colour takes place in the method of Fiske \& Subbarow which continues for more than $72 \mathrm{hr}$. (McCune \& Weech, 1940), while the colour produced by stannous chloride is stable. It may be suggested that the reduction of the first two molybdate residues of the phosphomolybdate complex is much faster than the reduction of the next seven and that stannous chloride alone is a sufficiently strong reducing agent to bring about the reduction of all nine groups in a short time at room temperature. At a temperature of $100^{\circ}$ the reduction of all nine groups is fast even with the weaker reducing agents.

It is probable, therefore, that the effect of Lutwak \& Sacks is largely due to the fact that the colour was developed under conditions which produce an extinction about 4-5 times higher than that which is produced in the reaction used for the preparation of the reference solution. Stannous chloride methods are much less subject to, even perhaps quite free from, this error, and are therefore more suitable for the investigation of the problem under discussion.

\section{SUMMARY}

1. Lutwak \& Sacks (1953) recently found that, when solutions of organic phosphates were heated with molybdate, estimations of inorganic phosphate by direct colorimetry and by colorimetry after previous precipitation did not agree.

2. It has now been shown that this effect is observed only when a blue colour develops during the exposure to heat. The effect is similar whether the solution contains, e.g. fructose phosphate or a mixture of fructose and phosphate, and is therefore unlikely to be due to the formation of organophosphomolybdate complexes. 
3. It is suggested that the effect is due to three factors. (a) If magnesia mixture is added to the reduced phosphomolybdate complex and the resulting precipitate analysed colorimetrically, recoveries of inorganic phosphate are low. (b) Free molybdic acid is reduced, giving molybdenum blue. Contrary to prevailing opinions, molybdenum blue is extracted from acid solutions by isobutanol. (c) The specific extinction coefficient is about 4-5 times higher when the colour of the reduced phosphomolybdate complex is developed at $100^{\circ}$ than when it is developed at room temperature. This is true for most reducing agents except stannous chloride, with which a higher extinction is obtained at room temperature.

4. The effect is not observed under the milder experimental conditions of Weil-Malherbe \& Green (1952). If it had occurred, a stannous chloride method of phosphate estimation, such as was used by these authors, would have been less subject to error than a method using aminonaphtholsulphonic acid.

The author is indebted to Mr R. H. Green for much technical assistance.

\title{
REFERENCES
}

Berenblum, I. \& Chain, E. (1938). Biochem. J. 32, 286. Boltz, D. F. \& Mellon, M. G. (1947). Ind. Engng Chem. (Anal.), 19, 873.

Davies, D. R. \& Davies, W. C. (1932). Biochem. J. 26, 2046. Fiske, C. H. \& Subbarow, Y. (1925). J. biol. Chem. 66, 375. Fontaine, T. D. (1942). Ind. Engng Chem. (Anal.), $14,77$. Griswold, B. L., Humoller, F. L. \& McIntyre, A. R. (1951). Analyt. Chem. 23, 192.

Kuttner, T. \& Cohen, H. R. (1927). J. biol. Chem. 75, 517. Lowry, O. H. \& Lopez, J. A. (1946). J. biol. Chem. 162, 421. Lutwak, L. \& Sacks, J. (1953). J. biol. Chem. 200, 565.
McCune, D. J. \& Weech, A. A. (1940). Proc. Soc. exp. Biol., N.Y., 45, 559.

Martin, J. B. \& Doty, D. M. (1949). Analyt. Chem. 21, 965.

Norberg, B. (1942). Acta physiol. scand. 5, suppl. 14.

Teorell, T. (1931). Biochem. Z. 230, 1.

Umbreit, W. W., Burris, R. H. \& Stauffer, J. F. (1945). Manometric Techniques and Related Methods for the Study of Tissue Metabolism. Minneapolis: Burgess Publishing Co.

Weil-Malherbe, H. \& Green, R. H. (1952). Biochem. J. 49, 286.

\section{Studies with Marked Antisera}

\author{
QUANTITATIVE STUDIES WITH ANTISERA MARKED WITH IODINE 131ISOTOPE \\ AND THEIR CORRESPONDING RED-CELL ANTIGENS
}

\author{
By J. C. BOURSNELL, R. R. A. COOMBS AND VIVIEN RIZK \\ Departments of Biochemistry, Animal Pathology and Pathology, University of Cambridge
}

\section{(Received 8 August 1952)}

By now a considerable number of workers has begun to use the radioisotope technique in investigations on serological and immunological phenomena (see review by Francis, Mulligan \& Wormall, 1951). These methods enable one to trace quantitatively suitably marked antibodies and antigens in amounts beyond the range of any other known methods. The object of the present investigations was the study of the combination of specific serum antibodies with antigens on the red-cell surface by quantitative isotopic methods. Such a study entails marking the antibody molecules in an antiserum with an isotope and allowing the marked antiserum to react with a suspension of red blood cells. The cells are then washed free of uncombined protein and the radioactivity of the washed, sensitized cell suspension measured.

Because of the necessity of washing the sensitized cell suspensions free of all uncombined serum proteins, antigen-antibody systems had to be chosen which do not produce strong agglutination or clumping of the cells, since it would not be possible to wash the aggregates free of all protein other than that specifically bound to the cell, and haemolysis would probably occur if an attempt were made to break them up by mechanical agitation. The following red-cell antigen-antibody systems are suitable. (1) The so-called incomplete $\mathrm{Rh}$ antibodies (Race, 1944; Wiener, 1944) combine with the red-cell antigens but for some reason, as yet unknown, fail to bring about agglutination. We have used the incomplete anti-D Rh antiserum with Rhpositive human red cells. (2) The red cells of certain oxen, owing either to the disposition of the antigens on the cell surface, or to some other physical property of their surface, remain unagglutinated when sensitized by potentially agglutinating antibodies. We have used bovine red cells of the 'in. 